\title{
Liquefaction Structures from a High-Magnitude Paleoseismic Event at about 12,400 C14-Years BP in Southern Sweden
}

\author{
Nils-Axel Mörner \\ Paleogeophysics \& Geodynamics, Stockholm, Sweden \\ Email: morner@pog.nu
}

How to cite this paper: Mörner, N.-A. (2017) Liquefaction Structures from a HighMagnitude Paleoseismic Event at about 12,400 C14-Years BP in Southern Sweden. Open Journal of Earthquake Research, 6, 216-227.

https://doi.org/10.4236/ojer.2017.64014

Received: September 28, 2017

Accepted: November 6, 2017

Published: November 9, 2017

Copyright $\odot 2017$ by author and Scientific Research Publishing Inc. This work is licensed under the Creative Commons Attribution International License (CC BY 4.0).

http://creativecommons.org/licenses/by/4.0/

\begin{abstract}
The Swedish catalogue of paleoseismic events includes 64 separate events. The seismic activity was especially high, in magnitude and frequency, in the Late Glacial with peak rates of glacial isostatic uplift. At about 12,400 C14-years BP $(14,600 \mathrm{cal} \cdot \mathrm{yrs} \mathrm{BP})$, there was a very strong event on the Swedish west coast. The magnitude was estimated at $M>8$. It was linked to intensive liquefaction and a major tsunami event. In this paper we describe sedimentological structures of liquefaction, ground shaking and tsunami wave actions from the Hunnestad gravel pits, to the east of the city of Varberg on the Swedish West Coast. The liquefaction structures documented offer impressive and educational insight into the process of liquefaction at high-magnitude earthquakes.
\end{abstract}

\section{Keywords}

Paleoseismics, Liquefaction, Tsunami, Late Glacial, Kattegatt Sea, Sweden

\section{Introduction}

Sweden has turned out to have been an area of high seismicity in magnitudes as well as in frequency [1] [2]. This was primarily the case in deglacial time when the rates of glacial isostatic uplift amounted to tens of centimeters per year. The First Paleoseismic Catalogue of Sweden included 52 events [2], and the Second Paleoseismic Catalogue 64 events [3]. Events of magnitudes estimated at M 8 or even $M>8$ were recorded and documented [2]. In the Stockholm area, 7 events were recorded within 102 varve years [4]. Even in the last 5000 years as many as 11 paleoseismic events were recorded. Recent analyses [5] [6] have shown that some of them may even have amounted to $\mathrm{M} \sim 8$.

The Swedish West Coast and the Kattegatt Sea are traversed by an active tectonic 
fault zone [7], [2] as shown in Figure 1. During the last 13,000 C14-years $(15,850 \mathrm{cal} \cdot \mathrm{yrs} \mathrm{BP})$ a total of 13 paleoseismic events have been documented on the Swedish West Coast (Figure 2). This paper will focus on the deformational structures of the 12,400 C14-years BP (14,600 cal-yrs BP) paleoseismic event [2] observed in gravel pits at Hunnestad located $9 \mathrm{~km}$ east of the city of Varberg. This site was the target for a paleoseismological excursion in 2008 [8] and a seismological excursion in 2013 [9] because of its excellent records of liquefaction structures, ground-shaking deformations and tsunami effects [2] [9].

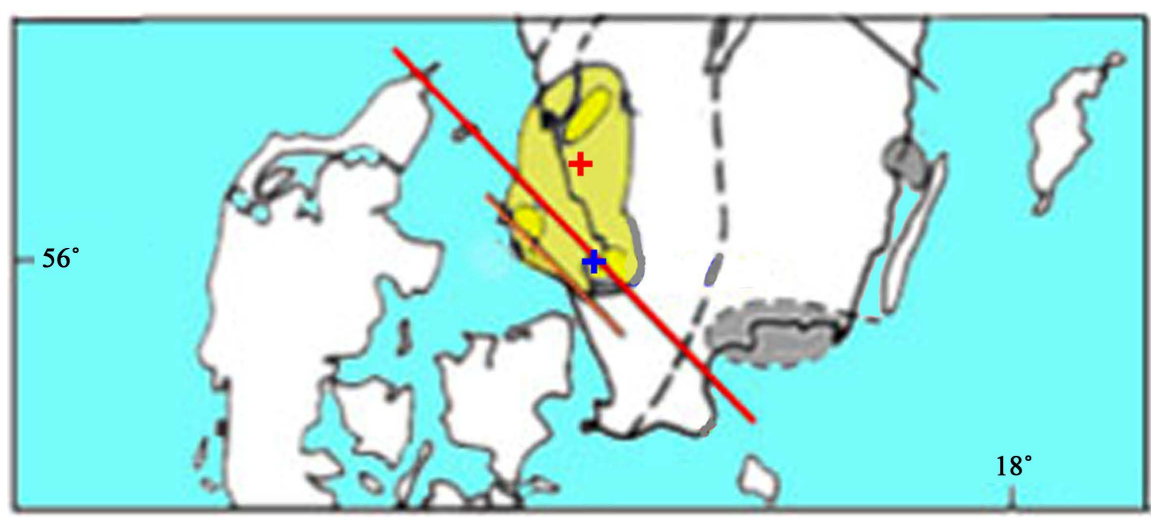

Figure 1. A major active fault (red line) from the northeast side of the Mt. Hallandsåsen Horst crossing the Kattegatt Sea in NW-direction (revized from [10]). Hunnestad liquefaction and tsunami site (red + ), Hovs Hallar seismotectonic site (blue + ), area seismically affected (yellow).

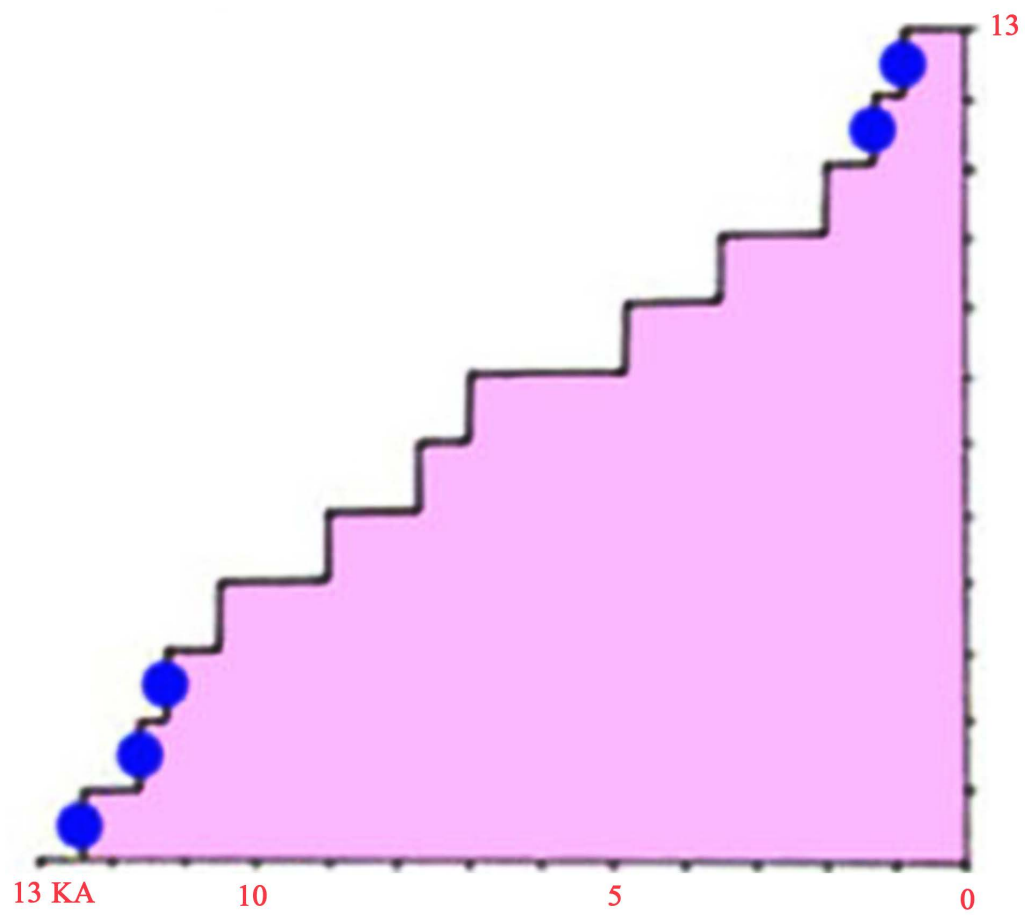

Figure 2. Therteen papeoseismic events have been documanted in the Kattegatt-West Coast refion during the last 13,000 C14-years BP [2] [4] [6]. Blue dots refer to tsunami events. 


\section{Previous Work}

The site was first described in [7] as an example of an ice marginal terminal moraine of stratified glacifluvial drift on the coastal plane of the County of Halland (Figure 3). The area was deglaciated at about 12,600 C14-years BP. At about $12,700 \mathrm{C} 14$-years BP, the marine fauna recorded a general change from arctic to boreo-arctic conditions. This was the onset of the Ågård Interstadial (or Early Bölling Interstadial), lasting 12,700 - 12,400 C14-yrs BP [7]. At about the same time, drop-stones of Cretaceous chalk and flint from the Strait of Öresund were deposited on the coastal plane of Halland. There were even pebbles with attached barnacles deposited in the littoral sand and gravel.

The Quaternary map of the area [11] discusses the stratigraphy in the Hunnestad gravel pits. It is claimed the there are records of subaerial cryoturbation (ice wedge casts), covered by a littoral unit including drop-stones of chert and flint, which the author took as evidence of a transgression.

The fact, however, is that his cryoturbation structures have nothing to do with ice wedge casts, but are typical liquefaction structures and the covering littoral unit a tsunami bed [2]. This is illustrated in Figure 4. All the paleoseismic characteristics are there; structureless sand, bowl and pillar structures, folds, venting dikes, fragmented beds, etc. The interpretation seems clear: a paleoseismic event liquefying the sandy beds and an associated tsunami throwing up a littoral gravel bed above, which includes small and large ice-blocks drifted from the Öresund

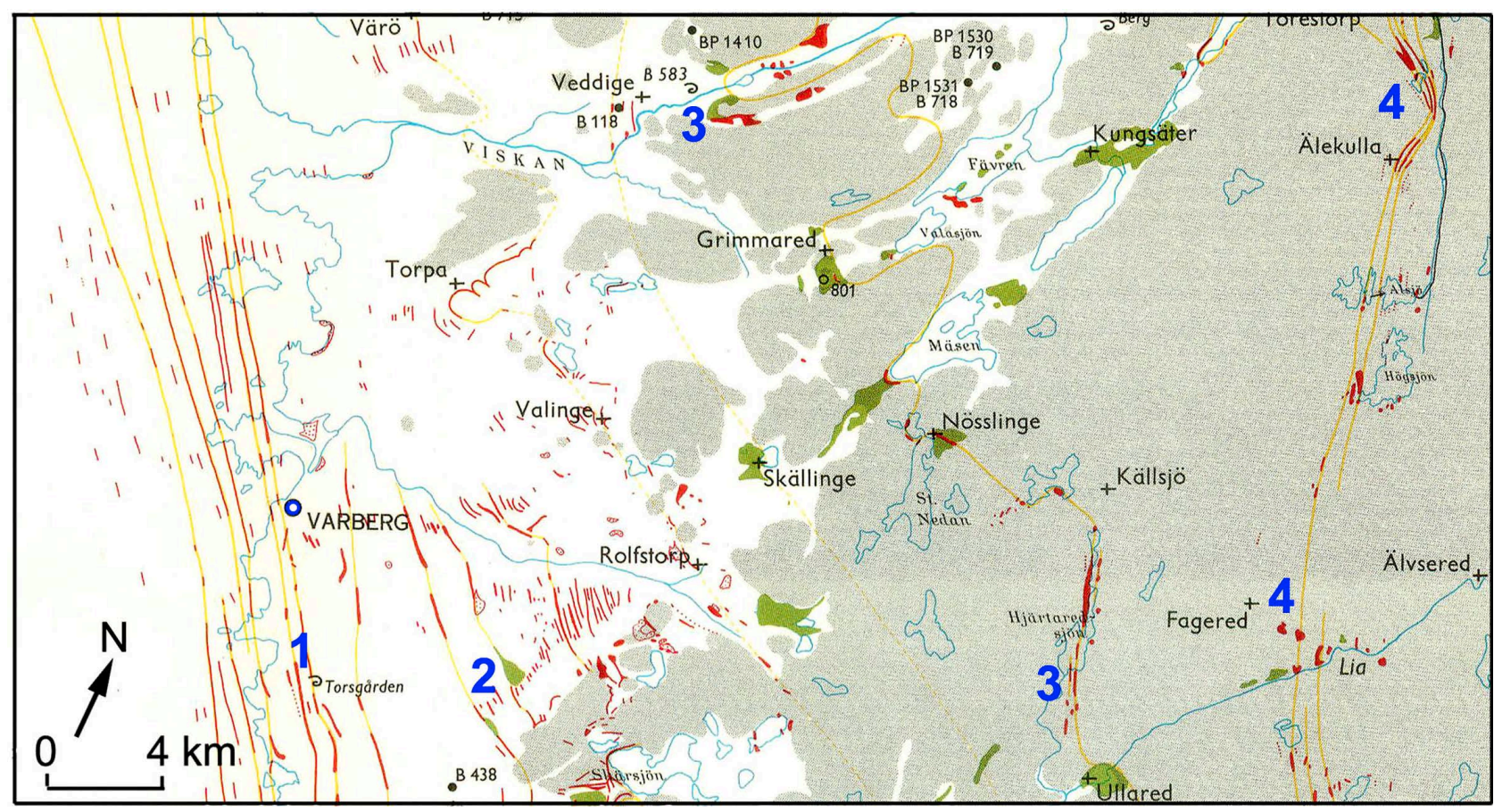

Figure 3. Ice recessional features on the Swedeish West Coast with shaded areas marking areas above the marine limit (as recorded by [7]); red = till ridges or accumulations, green = glacifluvial deposits, yellow lines = ice marginal positions. (1) the ice marginal position at 12,700 C14-years BP, (2) the glacifluvial deposits at Hunnestad, (3) the ice marginal position at the Fjärås Stadial, 12,400 C14-years BP (the Fjärås Line), and (4) the ice marginal position at the Older Dryas Stadial about 12,000 C14-years BP (the Berghem Line). 


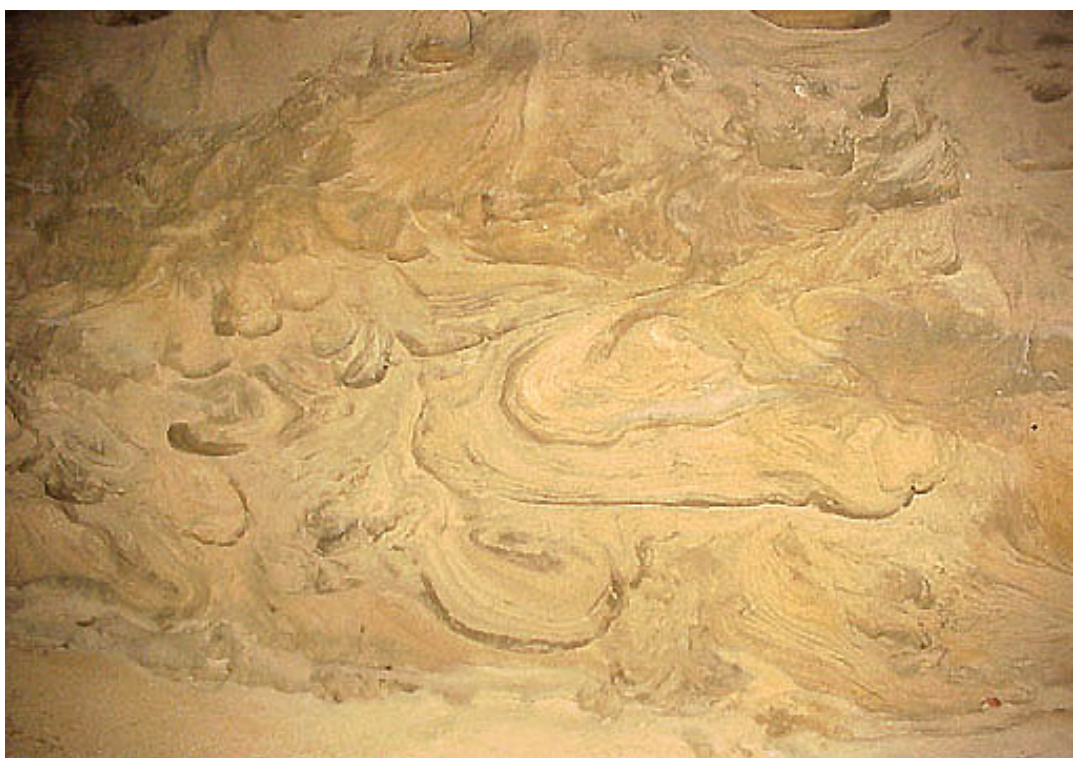

Figure 4. Liquefaction structure documented in 2003 in the Hunnestad gravel pit (at point 1 in Figure 5) [2]. The same structure was in the map description of the area erroniously classified as "ice wedges" [11]. The structures have nothing to do with ice wedge casts or any other types of cryoturbation, but provide clear evidence of liquefaction (with a covering tsunami bed).

region and dropping erratic clasts into the bed. The age of the paleoseismic event was 12,400 C14-years BP (14,600 cal-yrs BP), marking the onset of the Fjärås Stadial and the building out of the prominent ice marginal end-moraine zone known as the Fjärås Line [7].

The Hunnestad gravel pits were a stop at the ICG International excursion in 2008 [8]. At this stop, the participants dug up a number of excellent liquefaction structures. Further excavation was undertaken in 2013 in time for a seismological excursion the same year [9].

\section{Structures Observed}

Figure 5 gives an overview of the Hunnestad gravel pits as they look today (the western part now being strongly overgrown) with the sites mentioned in the text marked and numbered $(1-6)$.

Site 1 (Figure 1) was extensively cleaned up and documented in 2008. The new section is shown in Figure 6.

At Site 2, magnificent liquefaction structures were found in 2008. Figure 8 shows a mega-vent with a big block "swimming" in the liquefied sand. This calls for a high-magnitude liquefaction-triggering earthquake (cf. [2] and [12]). Figure 9 shows further liquefaction details from the same section.

At Site 3, there is a mega-structure of liquefied and deformed beds (Figure $10)$.

At Site 4, there is multiple vertical faulting of sand segments (Figure 11) accommodating pressure and mass movements due to the liquefaction. In the stratigraphic middle, there is a liquefied bed including "swimming" stones. 


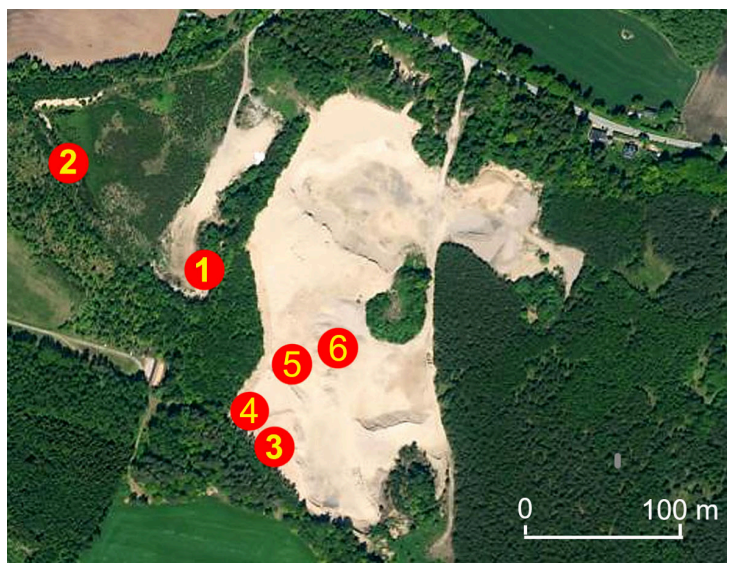

Figure 5. The Hunnestad gravel pits with investigation sites marked (red dots with numbers).

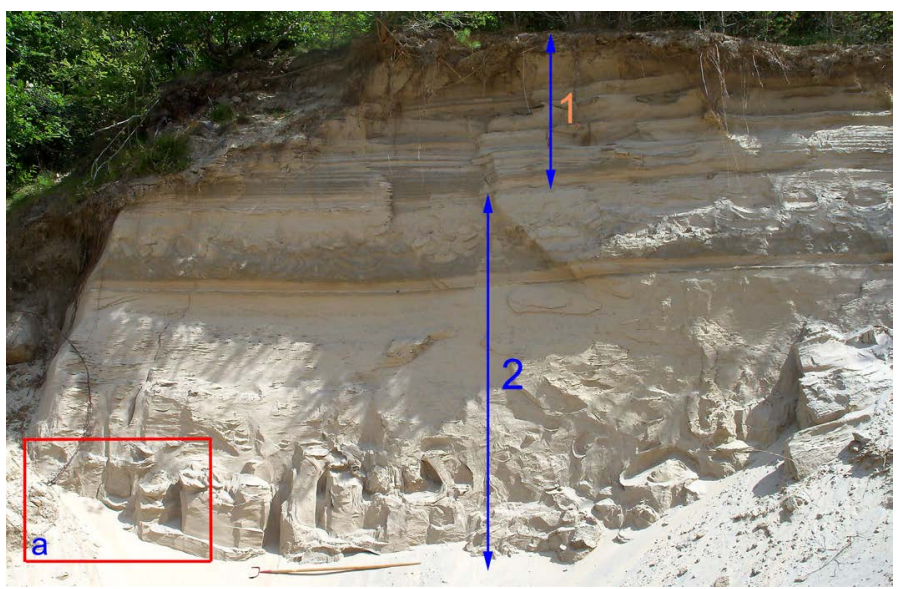

Figure 6. Stratigraphy at site 1: unit 1 represents back-swah tsunami deposits, and unit 2 strongly liquefied beds. Area (a) is enlarged in Figure 7.

At Site 5, a wedge of gravel and stones has moved westward floating or "swimming" on top of a liquefied bed (Figure 12 and Figure 13). The liquefied sand has penetrated through the gravel unit, and in front of the wedge, there is a major venting and mushrooming of the liquefied sand as illustrated in Figure 13. The mode of fluvial motion in similar structure has been studied by [14] applying magnetic methods.

Finally, Site 6 offers a very interesting view of stones that have been shaken down into "swiming" positions in liquefied sand. A similar shaking effect has been described from a early Holocene beach deposits [2] (op.cit. p. 250). This section offers quite exceptional records of shaking effect with respect to liquefaction and massive sinking-down and "swimming" of stones and blocks.

In conclusion, the Hunnestad gravel pit (Figure 5) offers an educational variety of excellent liquefaction structures (Figures 6-14), calling for a high-magnitude causation earthquake. Figure 14 redord massive sinking-down of stones into the liquefied sand due to the ground shaking. A tsunami height in the order of $10-15 \mathrm{~m}$ corresponds to an earthquake magnitude of $\mathrm{M} 8$ to $>8$ [6]. 


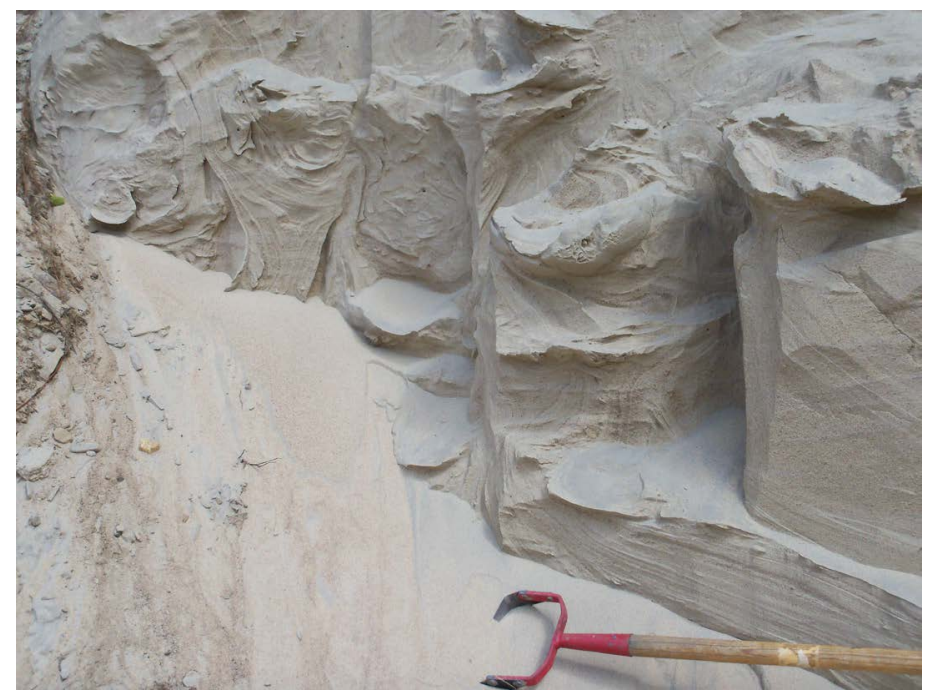

Figure 7. Heavy internal liquefaction of the lower bed in Figure 6; rectangle "a".

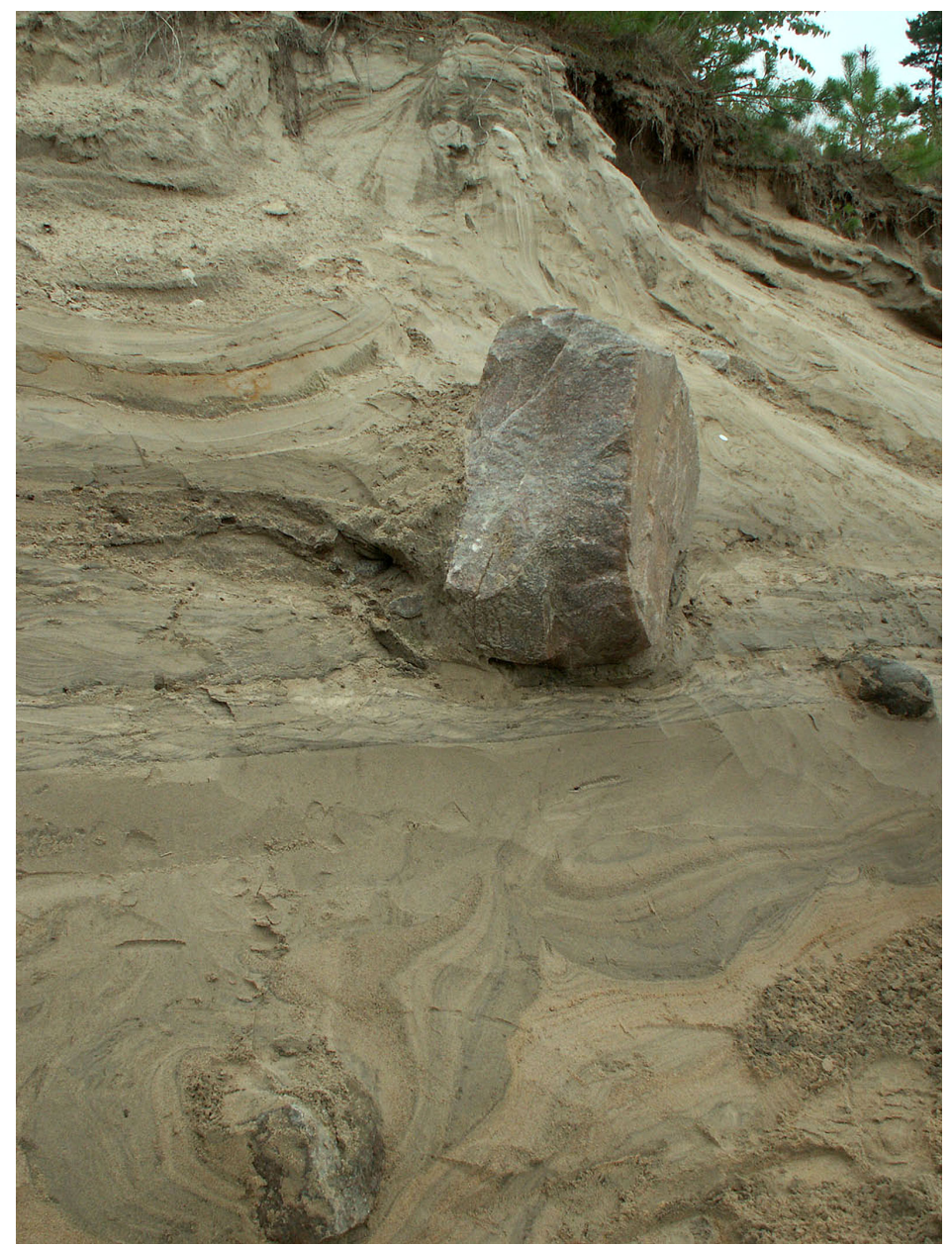

Figure 8. Stratigraphy at site 2. The big block is "swimming" in liquefied sand with a venting chimney above. These type of structures have been reported from other sites in Sweden [2] [12] and give evidence of violent ground shaking from high-magnitude earthquakes. Liquefied sand acts like a heavy fluid allowing heavy blocks and sediment fragments to "swim" in it (e.g. pp. 137, 156, 235 in [2]). 


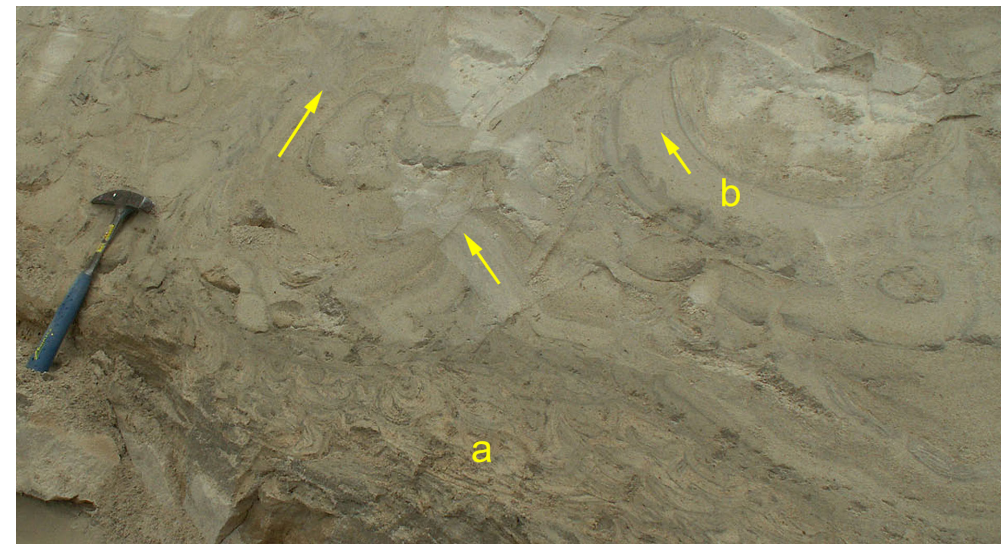

Figure 9. Structural details of the liquefaction at site 2. Yellow arrows give direction of motions of liquefied sand, where the one to the left gives a rising venting chimney. a is a strongly liquefied and contorted sequence; b shows a bowl structure sinking into a structureless liquefied sand where the direction of flow is recorded in the silt flames below (cf. [2] [12] [13]).

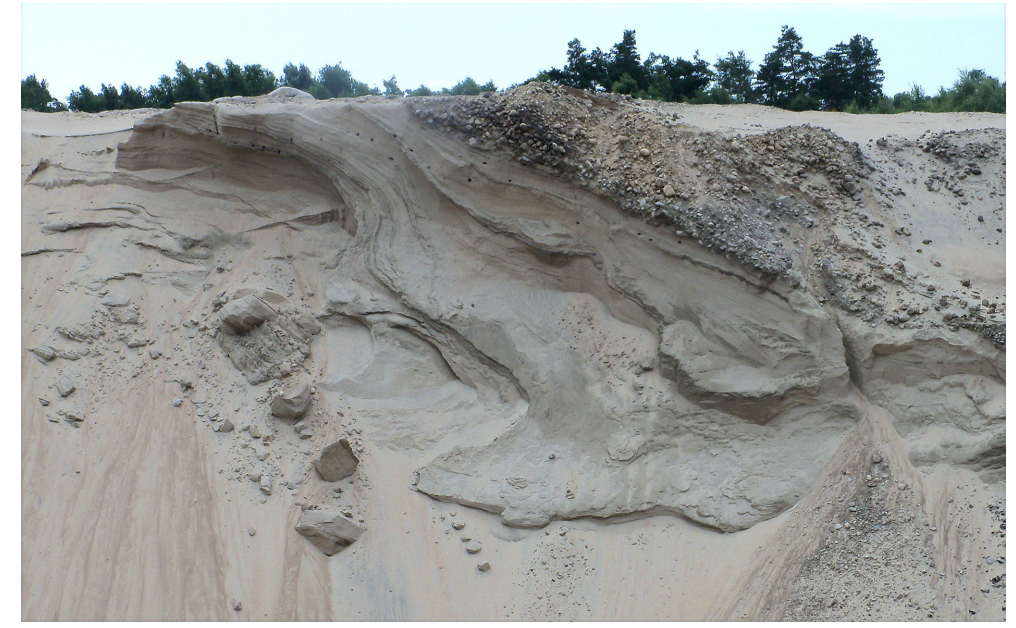

Figure 10. Strongly deformed and liquefied large-scale beds at Site 3 . The wall is $12 \mathrm{~m}$ high.

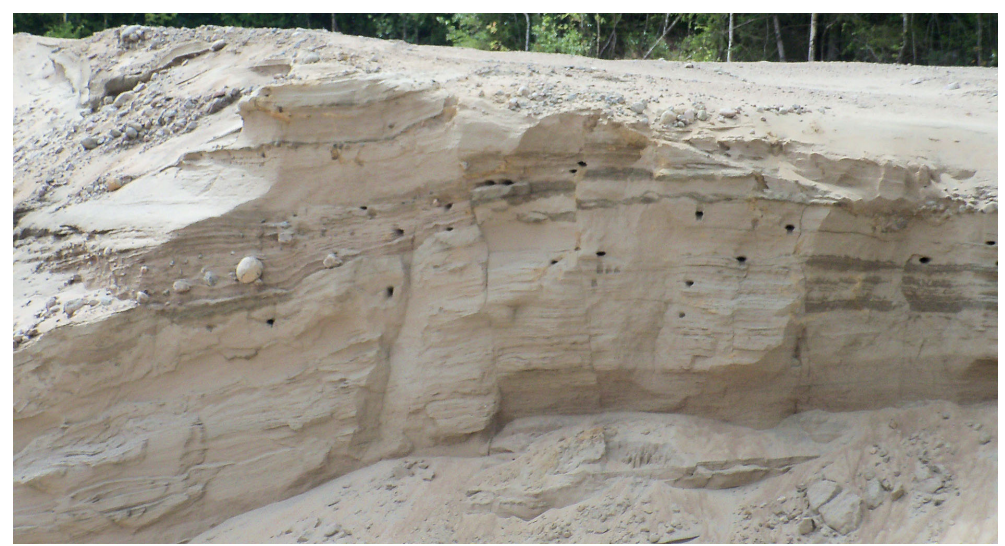

Figure 11. Site 4: faulted glacifluvial sand due to pressure and space acommodation from the liquefaction motions. In the middle there is a liquefied bed with "swimming" stones (cf. [2]). 

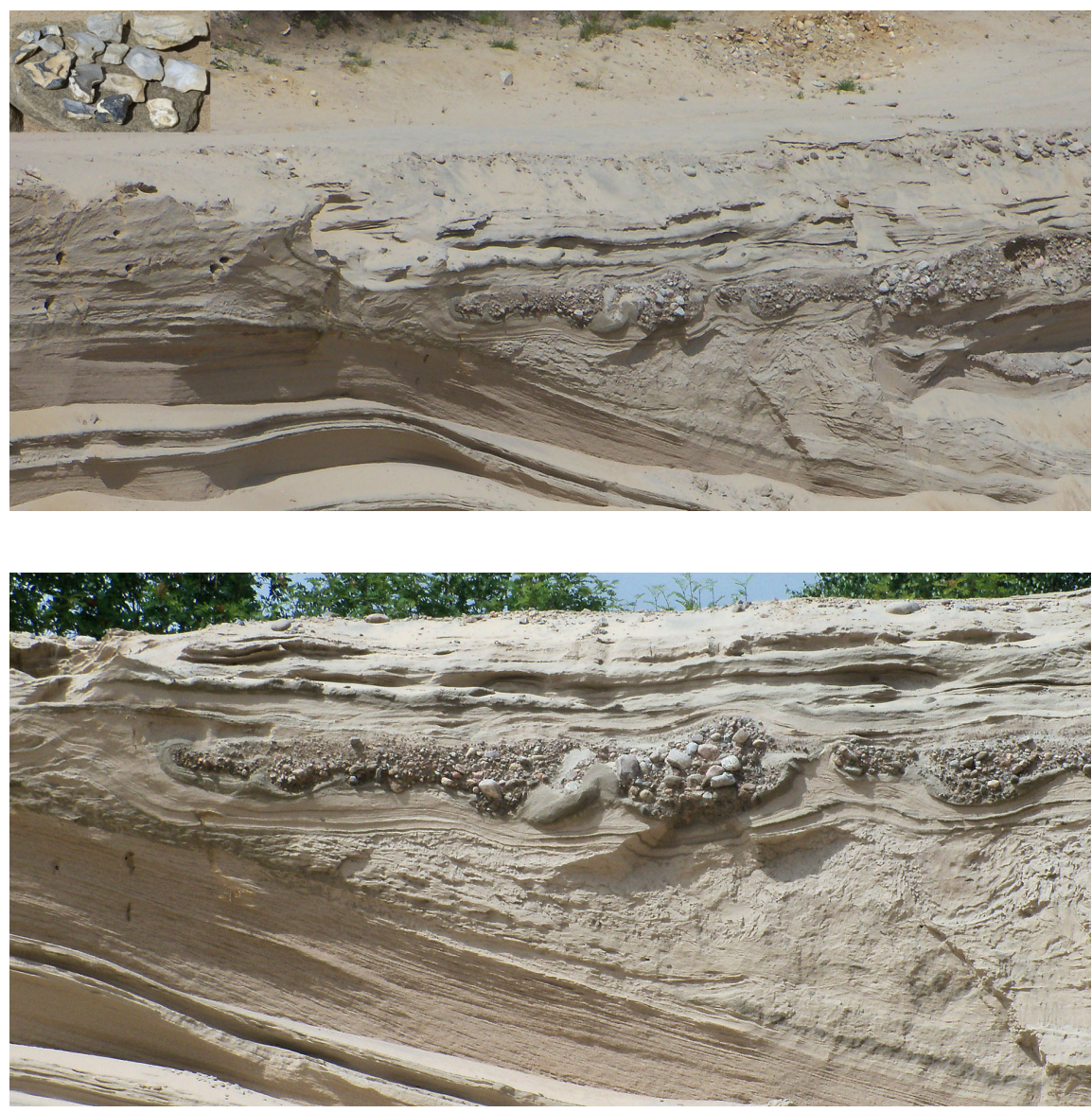

Figure 12. Site 5: a wedge of gravel has moved from right to left "swimming" on liquefied sand, over-turning and crumbling beds and venting in front of the wedge (lower image). The top layer is a tsunamite with flint fragments from the Öresund region (incerted image at top left picture).

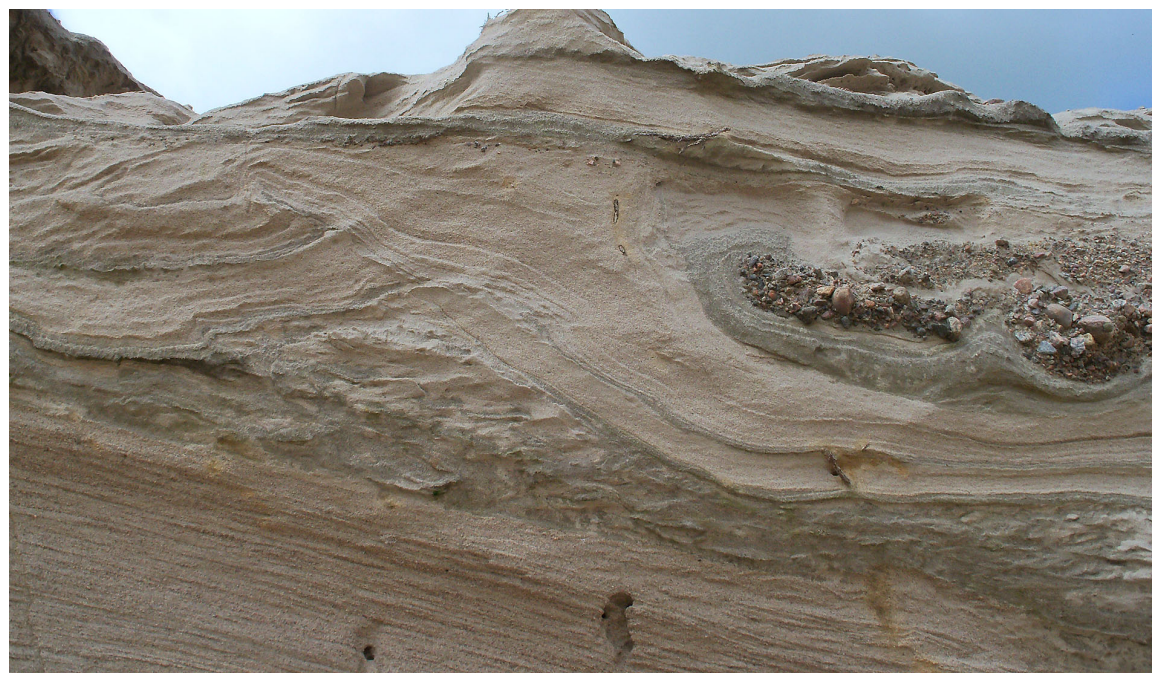

Figure 13. Colose-up of the deposits in front of the gravel wedge in Figure 12. Liquefied sand is venting upward in front of the gravel wedge, crumling the front as the vented material is mushrooming, and cutting across and pushing up over te beds in front (to the left). 


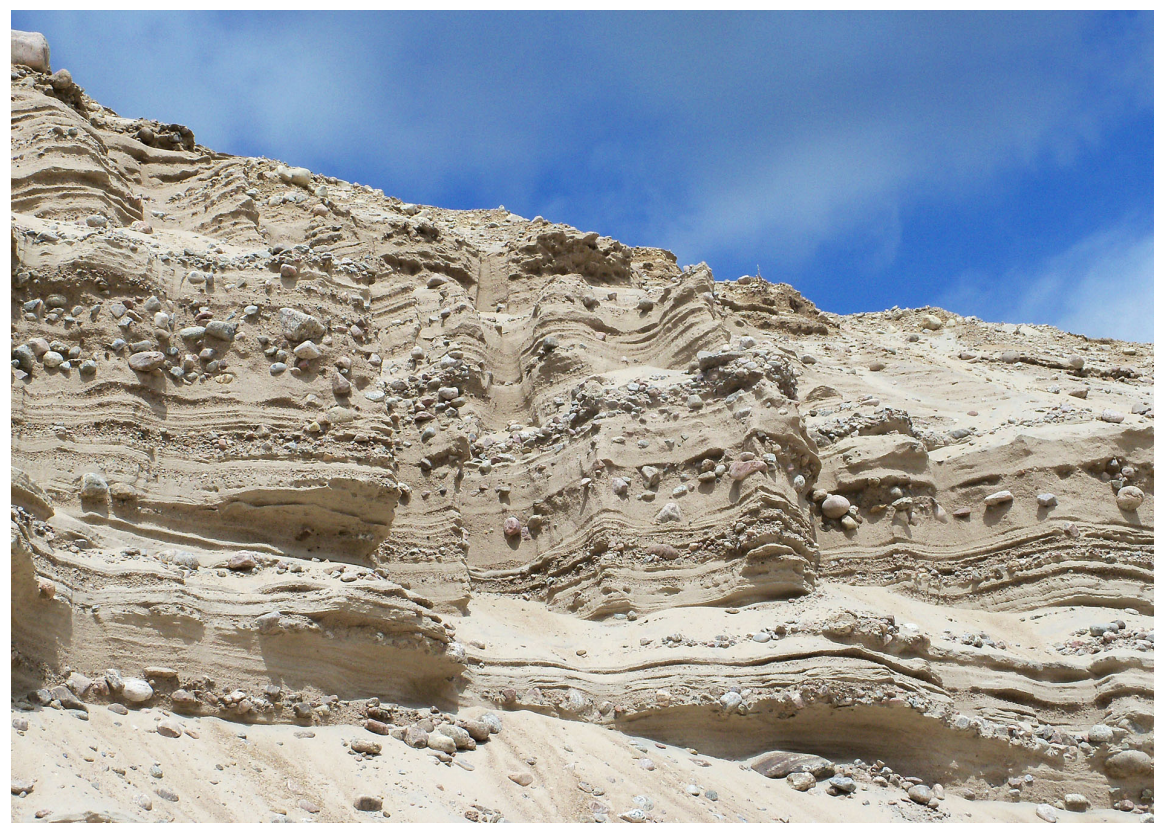

Figure 14. Site 6: The glacifluvial deposits have been shaken by a larg earthquake. This is evident from the massive sinking-down of stones into liquefied sand where they now occur in "swimming" position. This can only happen as a funktion of a high-magnitude earthquake [2] [9].

\section{Additional Seismotectonic Structures}

In the Båstad region (blue + mark in Figure 1), huge earth slides have been recorded along the Mt Hallandsåsen fault zone. These slides go down to the 12,400 C14-yrs BP shoreline [9] and were therefore interpreted as co-incidental to this shore position. This implies that they are of the same age as the liquefaction structure and tsunamite recorded in Hunnestad gravel pit.

In 2016, a new section was exposed of the Late Glacial surface at Hovs Hallar (Figure 15), previously hidden by a dense cover of junipers and blackberry.

The earthquake record at Hoves Hallar (Figure 15) fits perfectly well with the records documented in Hunnestad gravel pit (Figures 6-14). In addition, there are a number of other sites in the County of Halland where paleoseismic structures have been identified ([2], pp. 280-288). They were all ascribed to the Halland-1 paleoseismic ecent dated at 12,400 C14-yrs BP.

The Kattegatt Sea is traversed by a fault zone as illustrated in Figure 1 [2] [7]. It seems likely that the epicenter of the Halland-1 paleoseismic event and the deformations recorded in Hunnestad gravel pit (Figures 6-14) and the earthquake deformation at Hovs Hallar (Figure 15), all occurring at 12,400 C14-yrs BP, was located along the Kattegatt Fault zone. Therefore, it seems quite significan that [15] reported a strong faulting event in central Kattegatt within the time-window of 12,600 to 11,500 C14-yrs BP; i.e. very close to the age of the structures recorded along the Swedish West Coast (the Halland-1 event) sharply dated at 12,400 C14-yrs BP [2]. 



Figure 15. A slide of sharp-edged angular blocks not washed by the sea. The fracturing of the bedrock must have occurred after sea level had fallen (due to uplift) from the marine limit at $+50 \mathrm{~m}$ to the level of the $12,400 \mathrm{C} 14$-yrs BP shoreline at $+30 \mathrm{~m}$, where the slide ends and the marine abration of the block starts. This is indicative of a strong earthquake occurring at 12,400 C14-yrs BP at the same time as the earthslides in the Basstad region further to the east, and the extensive liquefaction and tsunami event recorded at Hunnestad [2] [9] here discussed.

\section{Possible Magnetic Grain Rotation}

The Gothenburg Geomagnetic Excursion or "Flip" occurred at 12,400 C14-yrs BP [16] [17] [18]. This implieas that it has the same age as the Halland-1 paleoseismic event [2]. Because we now know that earthquake shaking may significantly affect magnetic orientation [14], one may wonder if the Gothenburg Excursion or Flip might not be an artifact from the ground shaking of the 12,400 C14-yrs BP earthquake event ([2], p. 285). Paleomagnetic perturbation at about 12,400 C14-yrs BP has been recorded in 10 sites in southern Sweden and the Baltic covering an area of $300 \times 400 \mathrm{~km}$. If all those sites would have become internally deformed due to earthquake shaking [14], the corresponding earthquake must have been of a very high magnitude; $M>8$ or $>>8$. Some of the paleomagnetic records surely record true geomagnetic changes, however. This is, for example, surely the case with a core from the South Baltic (core St 2551), where a smooth paleomagntic departure of $180^{\circ}$ in declination and $0^{\circ}-20^{\circ}$ in inclination has been recorded in multiple samples [2]. This is further underlined by a beryllium spike just at the time of the Gothenburg Excursion [19]. This is 
indicative of a solar origin of the Gothenburg Excursion as further discussed in [19].

For the moment, it seems that some of the paleomagnetic departures documented originate from earthquake shaking, whilst other represent true geomagnetic field changes.

\section{Conclusions}

At 12,400 C14-yrs BP or 14,600 cal-yrs BP, there was a huge earthquake on the Swedish West Coast. In the Båstad region (blue + mark in Figure 1), huge earth slides have been recorded along the Mt Hallandsåsen fault zone. These slides go down to the 12,400 C14-yrs BP shoreline [9] and were therefore interpreted as co-incidental to this shore position. This implies that they are of the same age as the liquefaction structure and tsunamite recorded in Hunnestad gravel pit. This is "the Halland-1 paleoseismic event" of [2]. The deformations observed cover an area of $100 \times 300 \mathrm{~km}$, which implies a very large earthquake. The liquefaction structures observed in Hunnestad gravel pit are indicative a causational earthquake in the order of $\mathrm{M} 8$ or $M>8$. The tsunami height corresponds to an earthquake of $\mathrm{M} 8$ up to $\mathrm{M}>>8$. A magnitude of $M>8$ was previously proposed by [2]. With the new data from Hunnestad here presented, this estimate is confirmed, at least as up to an $\mathrm{M}>8$ magnitude.

The liquefaction structures recorded at Hunnestad are both impressive and educational for further understanding of liquefaction behavior due to intensive ground shaking by earthquakes. They may even serve as a standard of liquefaction structures formed at high magnitude earthquakes.

\section{Acknowledgements}

I acknowledge extensive digging and constructive discussions by the members of the 2008 ICG excursion [8]; viz. F. Audemard, T. Boski, C.F. da Silva, D. Easterbrook, E. Easterbrook, Y. Haruo, D. Inoue, Y. Kinugasa, N. Schroeder and I. Tamura, and constructive discussions with participants of the 2013 IASPEI excursion [9]; viz. S. Gregersen, B. Engdahl, P. Suhadolc, J. Adams, J. Dewey, J. Ebel, K. Haarstad, H. Li, A.K. Nandasena, M. Ando, G. Papadopoulos, A. van der Gusev, O. Pavlenko and R. van Nooyen.

\section{References}

[1] Mörner, N.-A. (1991) Intense Earthquakes and Seismotectonics as a Function of Glacial Isostasy. Tectonophysics, 188, 407-410. https://doi.org/10.1016/0040-1951(91)90471-4

[2] Mörner, N.-A. (2003) Paleoseismicity of Sweden-A Novel Paradigm. A Contribution to INQUA from Its Sub-Commission on Paleoseismology, at the $16^{\text {th }}$ Congress in Reno in 2003, P\&G-Print, 1-320.

[3] Mörner, N.-A. (2013) Pattern in Seismology and Paleoseismology, and Their Application in Long-Term Hazard Assessment. The Swedish Case in View of Nuclear Waste Handling. Pattern Recognition in Physics, 1, 75-89. 
https://doi.org/10.5194/prp-1-75-2013

[4] Mörner, N.-A. (2011) Paleoseismology: The Application of Multiple Parameters in Four Case Studies in Sweden. Quaternary International, 242, 65-75. https://doi.org/10.1016/j.quaint.2011.03.054

[5] Mörner, N.-A. (2017) Seismic Hazard Assessment: A Challenge for Science and Geoethics. International Journal of Engineering Hazard Mitigation, 4, 64-70.

[6] Mörner, N.-A. (2017) Converting Tsunami Wave Heights to Earthquake Magnitudes. Open Journal of Earthquake Research, 6, 89-97.

https://doi.org/10.4236/ojer.2017.62005

[7] Mörner, N.-A. (1969) The Late Quaternary History of the Kattegatt Sea and the Swedish West Coast: Deglaciation, Shorelevel Displacement, Chronology, Isostasy and Eustasy. Sveriges Geologiska Undersökning, C640, 1-487.

[8] Mörner, N.-A. (2008) Paleoseismicity and Uplift of Sweden. Guidebook, Excursion 11 at $33^{\text {rd }}$ ICG, Oslo 2008, 107 p. http://www.33icg.org/

[9] Mörner, N.-A. (2013) Seismotectonics of the Swedish West Coast. IASPEI Excursion Guide, July 27, 2013. Posted on ResearchGate, 2013. https://www.researchgate.net/publication/318901990

[10] Mörner, N.-A. (2004) Active Faults in Fennoscandia, Especially Sweden: Primary Structures and Secondary Effects. Tectonophysics, 380, 139-157.

https://doi.org/10.1016/j.tecto.2003.09.018

[11] Påsse, T. (1990) Beskrivning Till Kartbladet Varberg NO. Sveriges Geologiska Undersökning, Ae 102, 1-117.

[12] Mörner, N.-A. (2005) An Interpretation and Catalogue of Paleoseismicity in Sweden. Tectonophysics, 408, 265-307. https://doi.org/10.1016/j.tecto.2005.05.039

[13] Tröften, P.E. (1997) Neotectonics and Paleoseismicity in Southern Sweden with Emphasis on Sedimentological Criteria. PhD-Thesis, Stockholm University, P\&G Doctoral Thesis, 8, $124 \mathrm{p}$.

[14] Mörner, N.-A. and Sun, G. (2008) Paleoearthquake Deformations Recorded by Magnetic Variables. Earth and Planetary Science Letters, 267, 495-502. https://doi.org/10.1016/j.epsl.2007.12.002

[15] Jensen, J.B., Petersen, K.S., Konradi, P., Kuipers, A., Bennike, O., Lemke, W and Endler, R. (2002) Neotectonics, Sea-Level Changes and Biological Evolution in the Fennoscandian Border Zone of the Southern Kattegat Sea. Boreas, 31, 133-150. https://doi.org/10.1080/030094802320129944

[16] Mörner, N.-A., Lanser, J. and Hospers, J.P. (1971) Late Weichselian Paleomagnetic Reversal. Nature, 234, 173-174.

[17] Mörner, N.-A. and Lanser, J. (1974) Gothenburg Magnetic "Flip". Nature, 251, 408-409. https://doi.org/10.1038/251408a0

[18] Mörner, N.-A. (1977) The Gothenburg Magnetic Excursion. Quaternary Research, 7, 413-427. https://doi.org/10.1016/0033-5894(77)90031-X

[19] Mörner, N.-A. (2015) The Bölling/Alleröd-Younger Dryas Oscillation. In: Mörner, N.-A., Ed., Planetary Influence on the Sun and the Earth, and a Modern Book-Burning, Nova, New York, 79-90. 